\title{
Characterization and delimitation of the terroir coffee in plantations in the municipal district of Araponga, Minas Gerais, Brazil ${ }^{1}$
}

\author{
Caracterização e delimitação de terroirs de café em lavouras no município de \\ Araponga - MG
}

\author{
Samuel de Assis Silva ${ }^{2 *}$, Daniel Marçal de Queiroz $^{3}$, Francisco de Assis de Carvalho Pinto ${ }^{3}$ e Nerilson Terra \\ Santos ${ }^{4}$
}

\begin{abstract}
Differentiating coffees through the notion of terroirs allows us to determine potential areas for specialty coffee production and to characterize the type of coffee in these areas, exploring their potential. The objective of this work was to study spatial variability quality and to characterize and delimit terroirs in coffee crop production in Araponga municipality, Minas Gerais State, Brazil, using sensorial evaluation. The data were collected from four crops, from altitudes ranging from 770 to $1270 \mathrm{~m}$, with the extract increasing from low to high. In each plot of crops, samples of cherry fruits were collected, dried, benefited, subjected to sensorial analysis and given grades ranging from 0 to 100 points for the global drink quality and relative characteristics of honey, body, acidity, flavor and equilibrium. The spatial variability of the quality was analyzed using the Moran Index. To define coffee production terroirs, average quality grades were compared through separation tests and the individual values of the plots were subjected to an analysis of groupings. The study was efficient in identifying terroirs for mountain coffee culture, therefore allowing coffees to be differentiated as a function of their production locations. Araponga has more than one coffee production terroir characterized by two distinct altitude extracts.
\end{abstract}

Key words: Geographical origin. Sensorial quality. Spatial variability.

RESUMO - A diferenciação dos cafés através da noção de terroir permite determinar áreas potenciais para a produção de cafés especiais e caracterizar o tipo de café dessas áreas, explorando suas potencialidades. O objetivo nesse trabalho foi estudar a variabilidade espacial da qualidade e caracterizar e delimitar terroirs de produção de café de lavouras no município de Araponga - MG a partir da avaliação sensorial dos frutos produzidos nas mesmas. Os dados foram coletados em quatro lavouras, as quais apresentam uma variação de altitude de 770 a $1270 \mathrm{~m}$, dentro de extrato crescente. Em cada talhão das lavouras, foram coletadas amostras de frutos cereja que, depois de secas e beneficiadas, foram submetidas à análise sensorial, onde foram atribuídas notas variando de 0 a 100 pontos para a qualidade global da bebida e também para características relativas à sua doçura, corpo, acidez, sabor e equilíbrio. A variabilidade espacial da qualidade foi analisada através do índice de Moran. Para a definição dos terroirs de produção de café, as notas médias de qualidade, foram comparadas através de testes de separação e os valores individuais dos talhões submetidos à uma análise de agrupamentos. O estudo foi eficiente para identificar terroirs para a cafeicultura de montanha, permitindo assim diferenciar os cafés em função dos seus locais de produção. O município de Araponga possui mais de um terroir de produção de café caracterizado por dois distintos extratos de altitude.

Palavras-chave: Origem geográfica. Qualidade sensorial. Variabilidade espacial.

\footnotetext{
*Autor para correspondêcia

'Recebido para publicação em 12/06/2012; aprovado em 25/08/2013

Parte da Tese de Doutorado do Primeiro Autor Apresentada à Universidade Federal de Viçosa

${ }^{2}$ Departamento de Ciências Agrárias e Ambientais, Universidade Estadual de Santa Cruz, Rod. Jorge Amado, km 16, Ilhéus-BA, Brasil, 45.662-900, sasilva@uesc.br

32Departamento de Engenharia Agrícola, Universidade Federal de Viçosa, Campus Universitário, Viçosa-MG, Brasil, 36.570-000, queiroz@ufv.br, facpinto@ufv.br

${ }^{4}$ Departamento de Estatística, Universidade Federal de Viçosa, Campus Universitário, Viçosa-MG, Brasil, 36.570-000, nsantos@ufv.br
} 


\section{INTRODUCTION}

The coffee tree is a species of varied productivity and quality, and significant alternation depending on the production site (FAGAN et al., 2011). This characteristic is the integrated result of production system factors such as production, topography, management, soil, climate and the plant itself (AGGELOPOULOU et al., 2010). All these facts taken together determine the concept of terroir, according to which each region can be represented as a territory where different degrees of variability influence the plant and affect final product characteristics (GOULET; MORLAT, 2011).

In the terroir concept, the location is given special connotation, where certain products are endowed with a unique identity that will influence production and impart different impacts upon its final characteristics (CADOT et al., 2012). Vazquez, Segade e Fernandes (2010) state that the terroir approach is ample and built upon a symbiosis of natural, technological and social factors, resulting in specificity of products.

Terroir has been widely employed in vine growing, and the influence of different factors linked to the characterization of terroirs on the composition and quality of grapes has been demonstrated by various authors (CADOT et al., 2012; CONRADIE et al., 2002; KOUNDOURAS et al., 1999, TESIC et al., 2001; Van LEEUWEN et al., 2004; ZOU et al., 2012). Such authors have reported in their studies that the differentiation of terroirs must begin with the identification of differences in product quality. From this initial point, other characteristics are meticulously assessed, such as microclimate, soil and geography, which influence coffee beverage quality (NARANJO et al., 2011; SILVA; LIMA; ALVES, 2010).

In the case of coffee, the possibilities of differentiation and segmentation go through an analysis of the beverage's final quality, especially for specialty coffees. Specialty coffee has a number of distinguishing attributes that include physical characteristics such as origin, variety, color and size; sensory characteristics such as flavor body and aroma; and even environmental and social concerns with production systems and farming conditions (DICUM; LUTTINGER, 1999).

Differentiation of coffees based on the terroir notion makes it possible to determine potential areas to produce specialty coffees and to characterize the type of coffee characteristic to these areas, thereby exploiting its potentialities. Goulet and Morlat (2011) state that the definition and characterization of terroirs is an excellent alternative to improve the accessibility of external markets to different types of coffees produced at a certain region, and consequently to a higher appreciation of its products, as is already the case with wine.
Together with these factors, Byers, Gioanucci e Liu (2008) affirm that demand for specialty coffees is growing throughout the world. This stimulates studies and assessments that seek the expression of attributes intrinsic to coffee quality, coming from interactions between the production environment, the genetic characteristics of plants, and also management practices (LÄDERACH et al., 2011).

In virtue of the above, the objective of this work was to study the spatial variability of quality, as well as to characterize and identify the boundaries of coffee production terroirs at plantations in the municipal district of Araponga, Minas Gerais, based on the sensory evaluation of coffee berries produced in them.

\section{MATERIAL AND METHODS}

The study was conducted during the 2010/2011 harvest at four plantations located in the municipal district of Araponga, in the Minas Gerais Zona da Mata region. The region's climate is tropical highland with rain during summer and average annual temperature around $19^{\circ} \mathrm{C}$ with variations between $12^{\circ}$ (minimum average) and $26^{\circ} \mathrm{C}$ (maximum average).

The plantations were thus identified: (A) Braúna (Braúna Farm); (B) JA_B (Lower João Andrade Farm); (C) JA_A (Upper João Andrade Farm); and (D) Serra do Boné (Serra do Boné Farm).

The work began with a topographical survey of coffee production areas using DGPS equipment with postprocessed differential correction. For the differential correction we used data from IBGE's Brazilian Continuous Monitoring Network (RBMC), located at the Federal University of Viçosa.

In parallel with the data survey, we coded and characterized each property's coffee planting fields. This involved the following factors: variety planted, plantation age and plant spacing per field. A planting field was considered to be an area with homogeneous farming characteristics: sun orientation, spacing, coffee variety and age, and path or contour-line bordering.

The varieties cultivated in the four plantations are basically the same, with predominance of catuaí and catucaí, both with red-colored berries. The Serra do Boné farm is the only one growing yellow-colored berries, with a small proportion of plants of the yellow catucaí variety and yellow bourbon variety. The plantations are 8 years old on average and the plants widely spaced, with a variation of 2 to $3 \mathrm{~m}$ between cultivation lines and 0.5 to $1 \mathrm{~m}$ between plants.

The plantations were chosen taking into consideration significant differences between them, 
especially with respect to altitude, so that four distinct strata would be formed within an interval sequence, as observed in Figure 1. Digital elevation models of the plantations were prepared with ArcGis 9.3 spatial analysis package, using the altitude of each of the 500 points sampled for this purpose in each of the plantations involved in the study.

The Braúna farm has an approximate area of 33 hectares with a total of 12 planting fields defined by the above listed criteria. The JA_B farm has an approximate area of 4.5 hectares with a total of 4 planting fields, whereas the JA_B farm has an approximate area of 3.9 hectares with a total of 3 planting fields. The Serra do Boné farm has an approximate area of 9 hectares with a total of 7 planting fields.

At harvest, 30 plants were sampled at random per hectare per planting field. Coffee cherries were manually picked from four branches of each plant, one pair on each side of the plant that faced the lanes. The choice of branches was made at random, so that the fruits would be representative of the plant and the section. The fruits collected were subsequently grouped to form a composite sample per planting field.

The sampled berries were peeled and artificially dried in drying air at $40{ }^{\circ} \mathrm{C}$ to an approximate water level of $12 \%$ mc using a tray drier with a gas burner. The dried samples were processed and stored in plastic packaging, and kept for an approximate period of two months up until the physical and sensory quality test.

Coffee quality was assessed based on the analysis of its physical characteristics and sensory analysis, popularly known as drinking test. Coffee sensory quality was assessed by cupping and considered its honey, flavor, acidity, body and equilibrium, which together form its global quality. The analyses followed national and international competition rules by the Specialty Coffee Association of America (SCAA) and were performed according to the association's sensory assessment form.

The sensory test (cupping) was performed by three cuppers, with only one determination per cupper per sample. Each sample was composed of five cups to be assessed in their sensory characteristics as described above.

Figure 1 - Digital elevation models for the Braúna, Higher João Andrade (JA_A), Lower João Andrade (JA_B) and Serra do Boné farms, in the municipal district of Araponga, MG
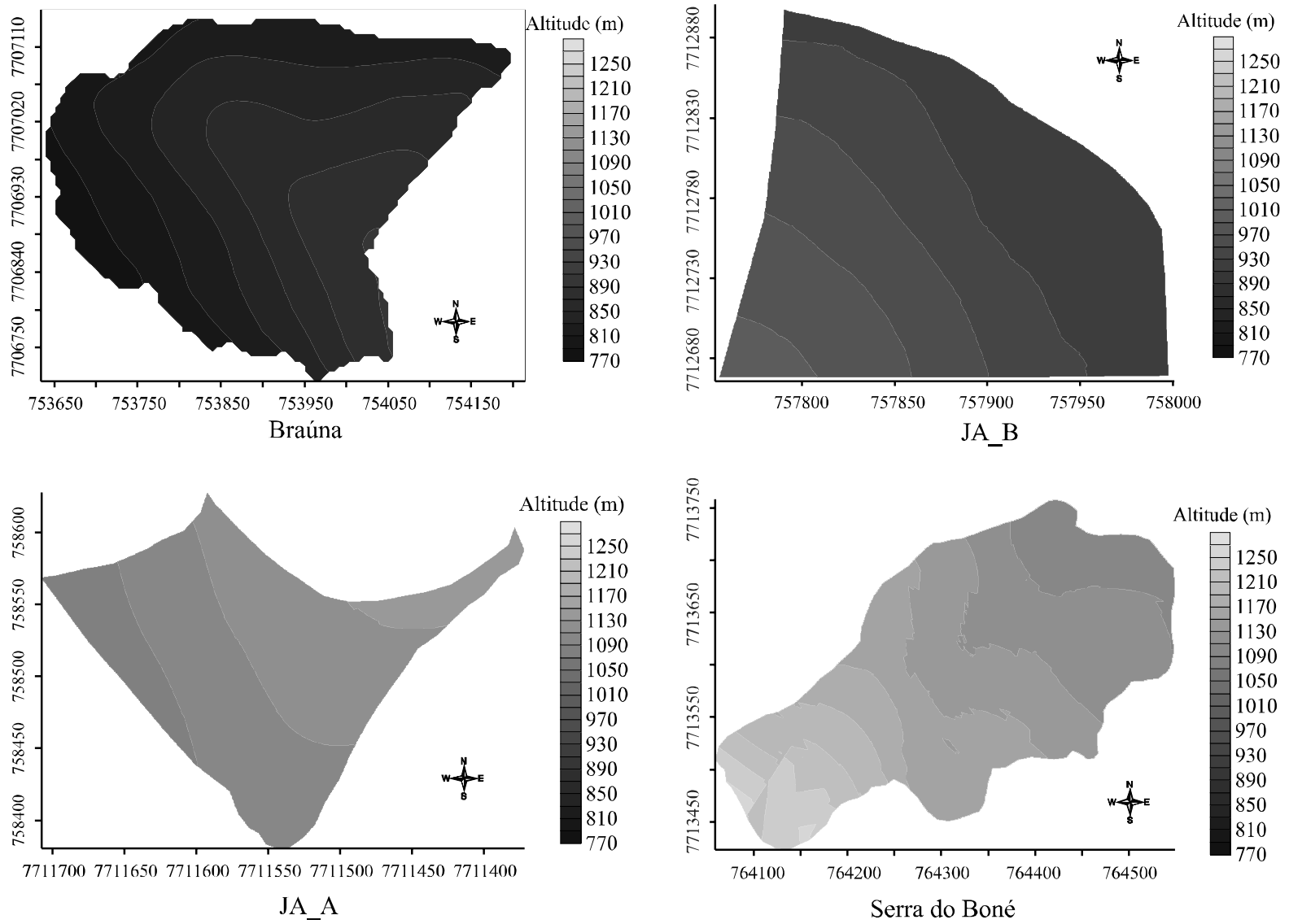
The analysis of this set of quality criteria determined the final global score of each sample, with calculation of quality criteria means and obtaining one single quality score per sample.

Initially, theme maps of the global beverage quality were generated for each one of the farms involved in the study. They were exported to ArcGIS 9.3 ArcMap for analysis of the spatial variability of quality.

Based on spatial variability maps of beverage quality, we conducted an autocorrelation study, or spatial arrangement of quality based on Moran's global index. This index was chosen because it is less influenced by the reduced number of samples than other similar indexes, such as Moran's local index, since it expresses the autocorrelation of a polygon considering only its first neighbor (DRUCK et al., 2004). Based on Z-test we tested the hypothesis of the arrangement being clustered or dispersed, seeking to define the spatial dispersion of the attribute studied in the defined area.

The delimitation of coffee production terroirs was conducted based on the differentiation of beverage quality obtained for the plantations. Global quality results and their individual characteristics (honey, flavor, acidity, body and equilibrium) were submitted to a separation test in order to identify significant differences between them. T-test was used to test independent samples at $5 \%$ probability for the null hypothesis of absence of significant difference between treatment means.

To confirm the results obtained from the separation test, the data was submitted to cluster analysis. These determinations were obtained using the Ward method as the cluster algorithm and Euclidean distance as the measure of dissimilarity (SILVA; LIMA, 2012).

Based on the assessment of this dissimilarity, we determined the cutoff point and therefore the number of classes or clusters into which the body of observations of coffee quality (global and individual) was divided. The cutoff point was obtained according to the visual dendrogram analysis criterion, when we identified the point at which we obtained the longest jump in Euclidean distance value for the clusters formed. This jump occurs when there is less variance inside groups and more variance between groups. Therefore, a long jump suggests the existence of homogenous groups internally and distant from each other.

\section{RESULTS AND DISCUSSION}

An analysis of the dispersion of global quality beverage scores and its peculiar characteristics for each plantation is presented in Figure 2.
Based on this analysis it is possible to see that the highest global quality values were obtained for the Braúna and Serra do Boné farms, with a maximum score of 87 . The JA_B farm had a maximum score of 84 , whereas the JA_A farm had a maximum score of 86 .

In spite of the high global coffee quality value observed in the Braúna farm, this is where the widest amplitude (dispersion) of values occurred, varying between 76 and 87 with $50 \%$ of planting fields scoring between 82 and 85 . At the Serra do Boné farm, which also had the highest global quality value, the variation was small, with all planting fields scoring between 85 and 87 for global quality. According to Specialty Coffee Association of America - SCAA (2008) criteria, all coffee produced at the Serra do Boné farm is excellent and classified as special origin. Although the Braúna farm grows coffees in the same category, most of its coffees are in the coffee group considered very good and classified as premium coffee.

Coffee honey scores come to attention when analyzing the peculiar characteristics of each farm sample. They are higher for Sera do Boné, varying between 80 and 90, whereas the other farms scored a maximum of 85 . This is an indication that Serra do Boné has more potential than the other farms to produce sweeter coffees, which may be a characteristic imposed by the place of origin of the coffee grains.

In general, it can be said that the JA_B and JA_A farms have intermediary values for all characteristics except for acidity, which in JA_B had the lowest score of all farms.

Table 1 presents the values calculated for Moran's index and the spatial autocorrelation significance tests for quality scores at the four farms involved in the study. Moran's indexes indicate the behavior of autocorrelation, in which smaller values than the expected index demonstrate a trend for dispersion, whereas positive values indicate a clustering trend for contiguous areas.

The Braúna and JA_Afarms had a cluster pattern, rejecting the null hypothesis of null autocorrelation for the spatial distribution of planting field scores. The JA $\mathrm{B}$ and Boné farms had null autocorrelation. Therefore, it can be said that the spatial variability of quality is observed only at the Braúna and JA_A farms, the behavior of the other farms being considered random and not dependent on a pattern of distribution that can be explained. This pattern is especially due to the amplitude found for the farms as discussed previously, i.e., only those farms that scored the highest variations in global quality values displayed spatial variability for this variable. These results do not follow the pattern 
Figure 2 - Box plot of global coffee beverage quality and its forming characteristics for the farms involved in the study
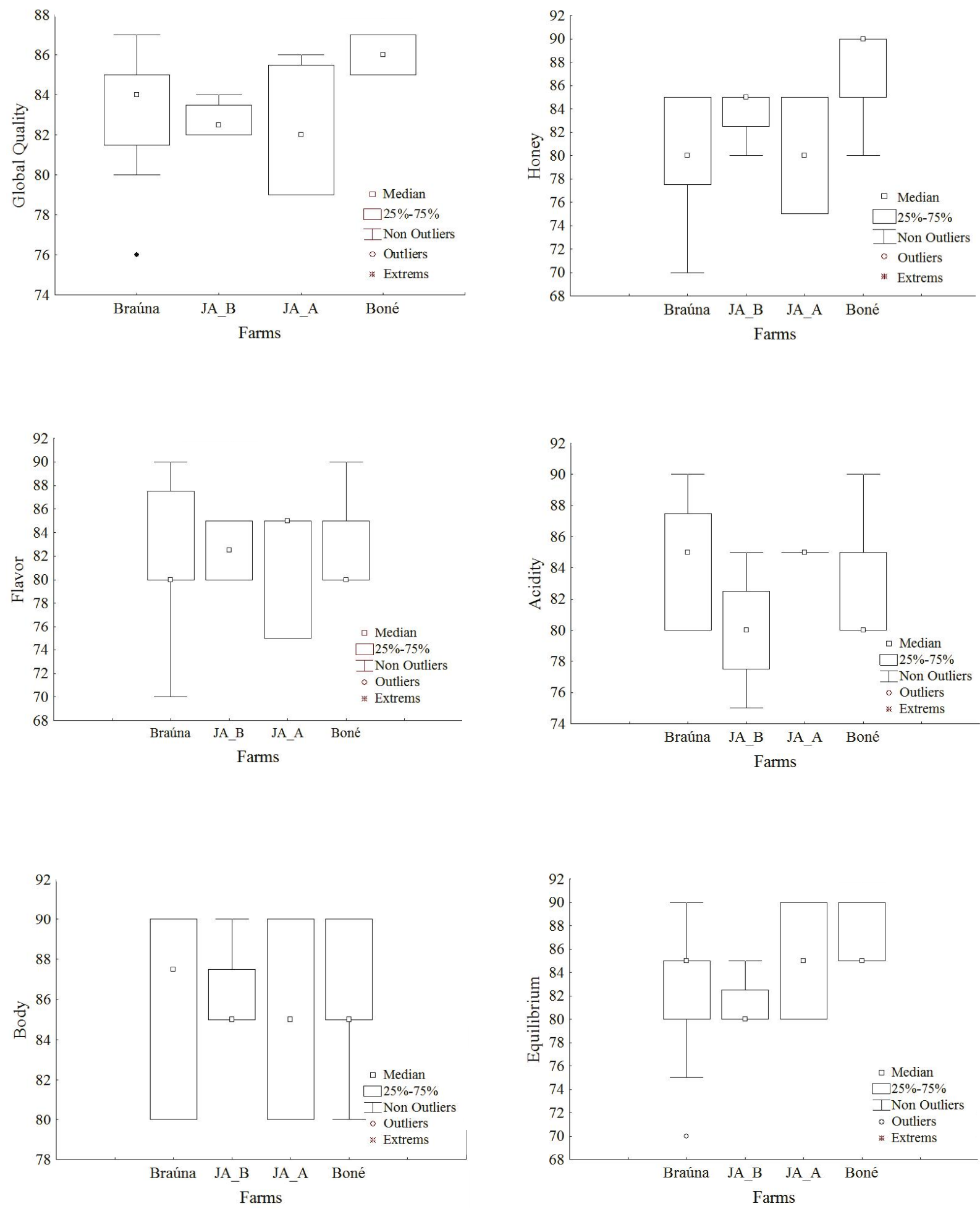

discussed by Alves (2009) when studying the spatial spatial distribution, since the trend is only regions that variability of mountain coffee quality. The author stand out in produced quality have spatial dependence, reports the possibility of a liaison between quality and which was not evidenced in the present work. 
Table 1 - Values calculated for Moran's Index and spatial autocorrelation significance tests for the plantations involved in the work

\begin{tabular}{|c|c|c|c|c|c|}
\hline \multicolumn{6}{|c|}{ Global Moran's Index } \\
\hline Farms & Moran's Index & Expected Index & Variance & Z-Score & p_Value \\
\hline Braúna & 0.32 & -0.09 & 0.07 & 1.57 & 0.02 \\
\hline JA_B & -0.88 & -0.33 & 0.09 & -1.86 & 0.06 \\
\hline JA_A & 0.92 & -0.33 & 0.77 & 1.42 & 0.01 \\
\hline Boné & -0.16 & -0.17 & 0.15 & 0.19 & 0.85 \\
\hline
\end{tabular}

The relationship between quality and spatial dependence is more evident when observing the spatial variability maps presented in Figure 3. The maps' scale was divided according to the SCAA key for sensory classification of special coffees.

As mentioned before, the Serra do Boné farm coffees were considered excellent quality and classified as special origin. Of the four planting fields in the JA_B farm, three produced coffees considered very good and classified as premium, whereas the other was classified as excellent.

At the other farm, one can observe higher variation in quality scores, since the Braúna farm has examples of coffees in the three classes proposed in the scale. Twenty five percent of the farm's planting fields produced coffee below special quality, $33 \%$ produced very good quality coffees and $42 \%$ of the planting fields produced excellent coffees.

Figure 3 - Spatial variability maps of the scores obtained for global coffee cherry beverage quality at the Braúna Farm, Upper João Andrade (JA_A) Farm, Lower João Andrade (JA_B) Farm and Serra do Boné Farm
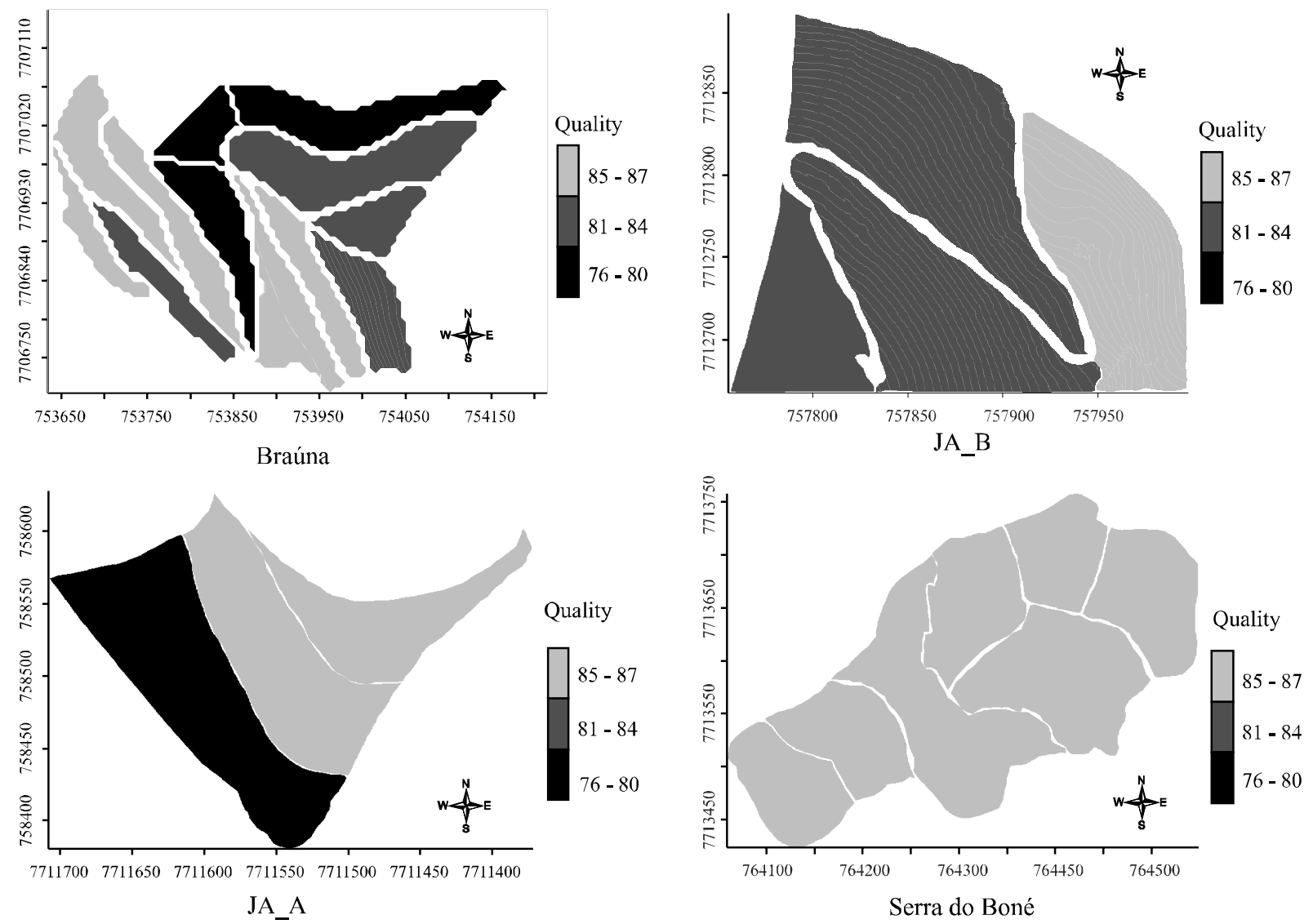
When analyzing global quality means and peculiar characteristics of each farm (Table 2) the difference between farms becomes clear.

We observe that global quality values were significantly different in comparisons between Serra do Boné and the other farms, although the Braúna Farm also has superior quality coffees, as mentioned earlier.

Honey and flavor had the same behavior as global coffee quality. Therefore, it is possible to infer that coffee produced at Serra do Boné is sweeter and set apart from the coffee produced at the other farms. Since the berries were processed according to standards for special coffee production and equally for all farm samples, everything suggests that this behavior is the result of local action where the coffee is produced, thereby confirming the hypothesis of this work that within a producing region in the state of Minas Gerais it is possible to identify quality characteristics that enable the definition of different coffee production terroirs.

According to Silva et al. (2004), coffee beverage honey comes from higher sugar values present in green coffee. Decazy et al. (2003) report that saccharose, which is the sugar present in largest quantities, is degraded during roasting, and is used in Maillard reactions and caramelization, giving origin to various volatile and nonvolatile compounds responsible for the sweet characteristic of coffees. Therefore it is possible to say that there is a tendency that the location of Serra do Boné favors the accumulation of sugars in green coffee, something that is not observed in the other farms.

With regard to other intrinsic qualities of coffee beverage, it was not possible to define differences among farms. Both acidity and body were not significantly different from one farm to another - it was a similar characteristic for all of them. Equilibrium had an intermediate structure for the JA_A farm and extreme structure for the Serra do Boné (upper limit) and Braúna and JA_B (lower limit) farms.
The characteristics with the most significant differences among farms based on the separation test presented on Table 2 were submitted to cluster analysis using the Ward method as algorithm and Euclidean distance as dissimilarity measure. This analysis was carried out with the purpose of identifying if the groups indicated in the separation test would be confirmed, and also to subsidize the confirmation of different coffee production terroirs in the municipal district of Araponga, Minas Gerais. The results of the cluster analysis can be found in Figure 4.

It is possible to see that, with exception of equilibrium, two different groups are formed in the plantations involved in the study. For the other three characteristics (global quality, honey and flavor) Serra do Boné is isolated in one group and the other farms make up the other group.

In light of the above, one can state that there are at least two coffee production terroirs in the municipal district of Araponga, Minas Gerais, one of which is characterized by a variation in altitude between 860 and 1090m, and the other with altitudes that go from the latter figure to a limit of $1270 \mathrm{~m}(\approx 1300 \mathrm{~m})$. It is general knowledge that altitude influences coffee quality, however, this influence is not always manifested in the same way in all productive regions. For example, while assessing the quality of coffees produced in the south of Minas Gerais, Silva et al. (2004) observed that coffees produced in the range from 920 to $1100 \mathrm{~m}$ had weaker body and acidity, and higher honey than those produced in the range between 720 and 920 meters. The results obtained by these authors differ from those found in the present study, since within this altitude stratum no significant difference was found between the sensory characteristics as reported by those authors. Therefore, it can be said that on most occasions, factors inherent to production and peculiar to each production region impart certain characteristics to coffee that sets it apart from other coffees, not necessarily in terms of global quality, but in individual sensory characteristics.

Table 2 - Quality variable means for farms involved in the study

\begin{tabular}{|c|c|c|c|c|c|c|c|c|c|c|c|c|}
\hline \multirow{3}{*}{ Farms } & \multicolumn{12}{|c|}{ Quality Variable } \\
\hline & \multicolumn{2}{|c|}{ Quality } & \multicolumn{2}{|c|}{ Honey } & \multicolumn{2}{|c|}{ Body } & \multicolumn{2}{|c|}{ Acidity } & \multicolumn{2}{|c|}{ Flavor } & \multicolumn{2}{|c|}{ Equilibruim } \\
\hline & Mean & $\mathrm{s}$ & Mean & $\mathrm{s}$ & Mean & s & Mean & $\mathrm{s}$ & Mean & $\mathrm{s}$ & Mean & $\mathrm{s}$ \\
\hline Braúna & $82.83 b$ & 3.67 & $80.83 b$ & 5.57 & $82.08 \mathrm{~b}$ & 6.20 & $84.16 \mathrm{a}$ & 4.17 & $85.83 \mathrm{a}$ & 4.68 & $82.08 b$ & 5.41 \\
\hline JA_B & $83.50 \mathrm{~b}$ & 2.95 & $83.75 b$ & 2.88 & $82.50 \mathrm{~b}$ & 4.08 & $80.00 \mathrm{a}$ & 4.50 & $86.25 a$ & 3.50 & $81.25 b$ & 3.97 \\
\hline JA_A & $82.25 b$ & 3.79 & $80.00 \mathrm{~b}$ & 5.77 & $81.67 b$ & 5.45 & $85.00 \mathrm{a}$ & 5.10 & $85.00 \mathrm{a}$ & 5.00 & $85.00 \mathrm{ab}$ & 5.00 \\
\hline Boné & $86.00 \mathrm{a}$ & 1.81 & $87.85 a$ & 2.67 & $86.42 \mathrm{a}$ & 3.77 & $82.85 a$ & 3.93 & $85.71 \mathrm{a}$ & 3.45 & $87.14 \mathrm{a}$ & 2.67 \\
\hline
\end{tabular}

$\mathrm{s}$ - standard error of the mean; Means followed by the same letter in the column do not differ statistically between themselves using T-test at $5 \%$ probability 
Figure 4 - Dendrogram of the cluster analysis for global quality (a), honey (b), flavor (c) and equilibrium (d) of coffee beverage values for the plantations studied

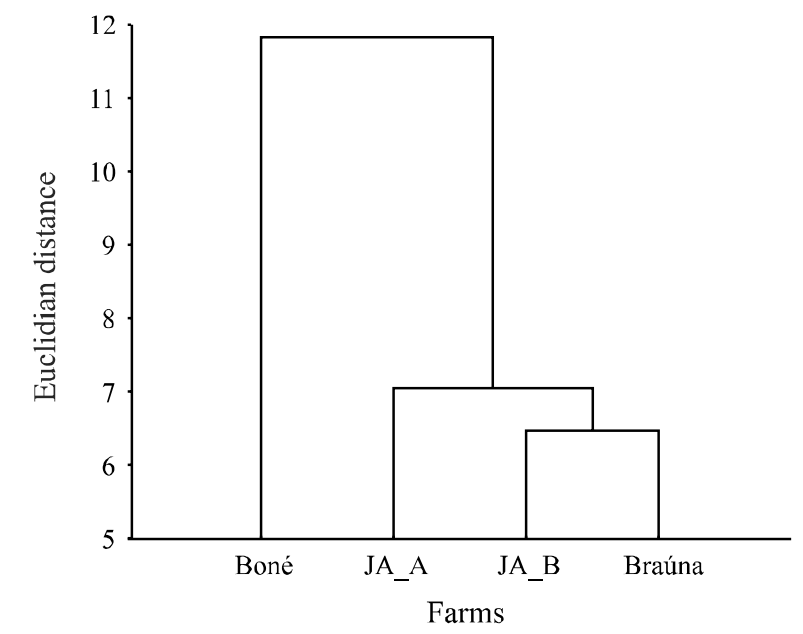

(a)

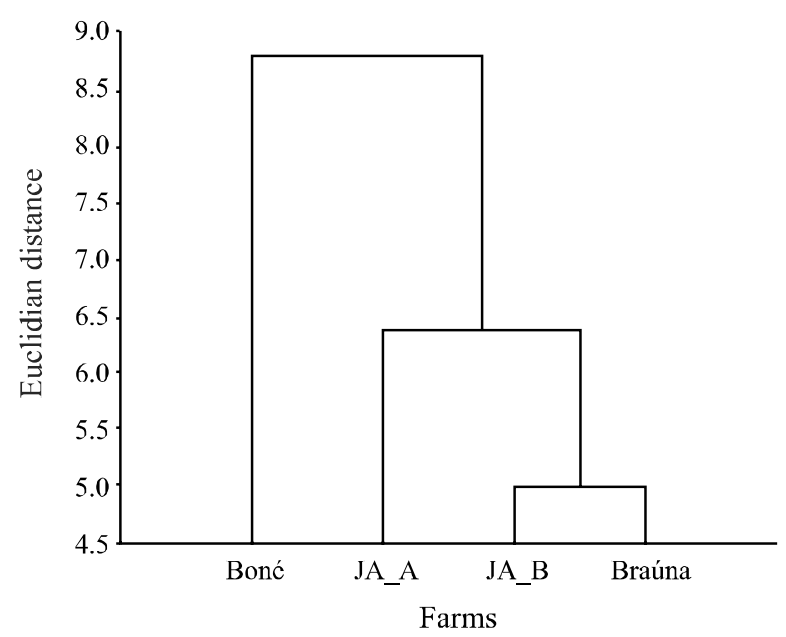

(c)

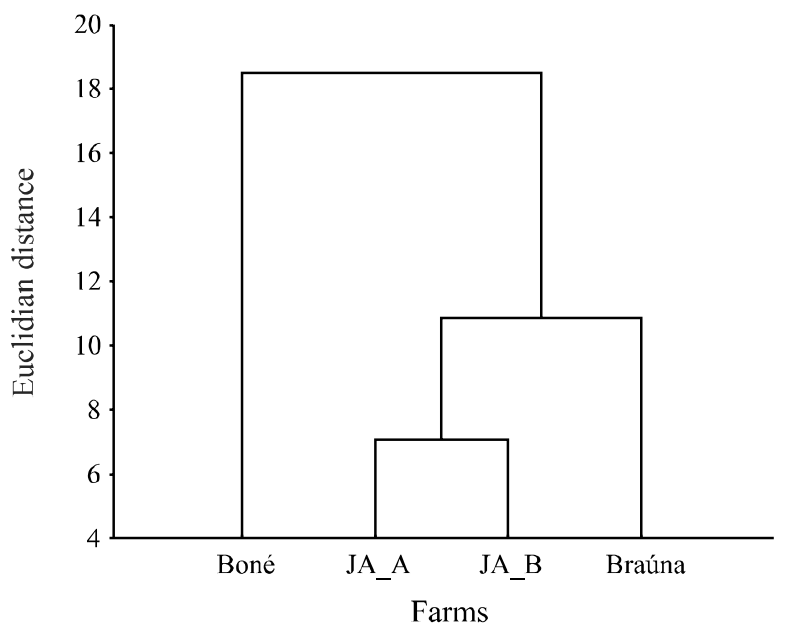

(b)

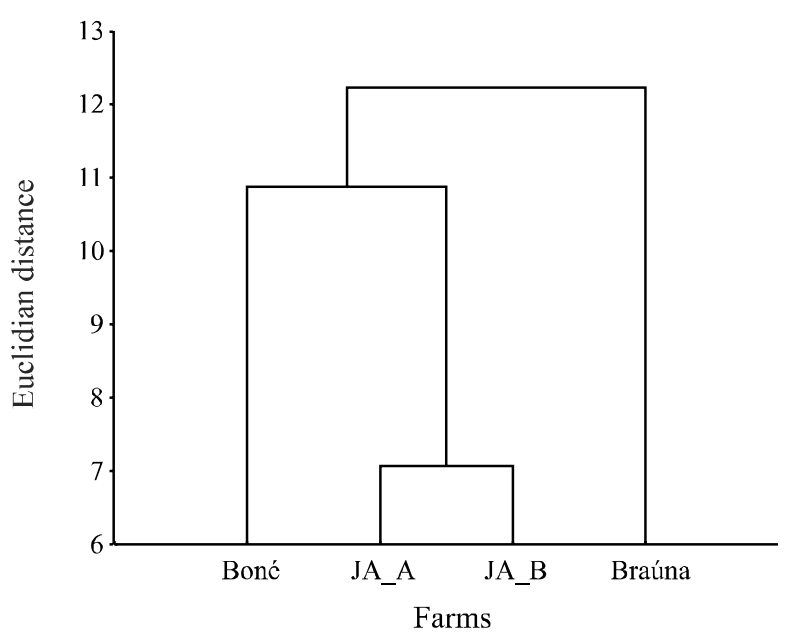

(d)

It is interesting to observe that it is possible to define different beverage standards following a geographic terroir pattern within a small area in comparison with the entire coffee production area in Brazil. It indicates that if research is expanded to larger areas involving different coffee production regions, it will be possible to define very specific patterns for each one and contribute significantly to value it in consumer markets. According to Cadot et al. (2012), introduction of the terroir notion in wine culture was fundamental to reach specific and increasingly demanding markets, based on the differentiation of terroirs. To Vazquez, Segade e Fernandes (2010), to differentiate a product based on its terroir is more than giving it a label with its specification of origin, but to make it carry a whole impression of a special place capable of producing a unique product. 
of the other farms was classified as random and not dependent on an explainable pattern of distribution;

2. The Serra do Boné farm stood out from the others based on its mean global quality and also in mean coffee honey and flavor values, whereas for the other characteristics this standard was not evidenced, therefore confirming the existence of a relationship between beverage quality and the characteristics of their production site;

3. The study was efficient in identifying potential terroirs for mountain coffee production, and therefore allowing the identification of a trend to differentiate coffees based on their production sites;

4. The municipal district of Araponga, Minas Gerais, has more than one coffee production terroir that can be differentiated based on quality variables and delimited according to the altitude of production sites.

\section{ACKNOWLEDGEMENTS}

The authors thank CNPq (The Brazilian National Counsel for Research and Development) for their support.

\section{REFERENCES}

AGGELOPOULOU, K. D. et al. Spatial variation in yield and quality in a small apple orchard. Precision Agriculture. v. 11, n. 01, p. $538-556,2010$.

ALVES, E. A. Variabilidade espacial e temporal da qualidade do café cereja produzido na região das Serras de Minas. 133 f. 2009. Tese (Doutorado em Engenharia Agrícola), Departamento de Engenharia Agrícola, Universidade Federal de Viçosa - UFV, Viçosa - MG, 2009.

BYERS, A.; GIOVANUCCI, D.; LIU, P. Value-adding Standards in the North American Food Market: trade opportunities in certified products for developing countries. Rome: Food and Agriculture organization of the United Nations, 2008, 88 p.

CADOT, Y. et al. Characterisation of typicality for wines related to terroir by conceptual and by perceptual representations. An application to red wines from the Loire Valley. Food Quality and Preference, v. 24, n. 1, p. 48-58, 2012.

CONRADIE, W. J. et al. Effects of different environmental factors on the performance of Sauvignon blanc grapevines in the Stellenbosch/Durbanville districts of South Africa. I. Geology, soil, climate, phenology and grape composition. South African Journal Enology Viticole, v. 23, n. 2, p. 78-91. 2002.

DECAZY, F. et al. Quality of different Honduran coffee in relation to several environments. Journal of Food Science, v. 68, n. 7 , p. $2356-2361,2003$.

DICUM, G.; LUTTINGER, N. The Coffee Book: anatomy of the industry from crop to the last drop. New York: The New York Press, 1999. 196 p.
DRUCK, S. et al. (Ed.) Análise Espacial de Dados Geográficos. Brasília, EMBRAPA, 2004.

FAGAN, E. B. et al. Efeito do tempo de formação do grão de café (Coffea sp) na qualidade da bebida. Bioscience Journal, v. 27, n. 5 , p. $729-738,2011$.

GOULET, E.; MORLAT, R. The use of surveys among wine growers in vineyards of the middleLoire Valley (France), in relation to terroir studies. Land Use Policy, v. 28, n. 4, p. 770-782, 2011.

KOUNDOURAS, S.; Van LEEUWEN, C.; SEGUIN, G.; GLORIES, Y. Influence de l'alimentation en eau sur la croissance de la vigne, la maturation des raisins et les caracteristiques des vins en zone mediterraneenne. Journal International des Sciences de la Vigne et du Vin, v. 33, n. 4, p. 149-160. 1999.

LÄDERACHA, P. et al. Systematic agronomic farm management for improved coffee quality. Field Crops Research, v. 120, n. 3, p. 321-329, 2011.

NARANJO, R. D. P. et al. Fingerprints for Main Varieties of Argentinean Wines: Terroir Differentiation by Inorganic, Organic, and Stable Isotopic Analyses Coupled to Chemometrics. Journal of Agricultural and Food Chemistry, v. 59, n. 14, p. 7854-7865, 2011.

SPECIALTY COFFEE ASSOCIATION OF AMERICA. Protocolo para análise sensorial de café - Metodologia SCAA. SCAA Cupping Protocols. Doc. 5, 2008. 13 p.

SILVA, R. F. et al. Qualidade do café-cereja descascado produzido na região Sul de Minas Gerais. Ciência e Agrotecnologia, v. 28, n. 6, p. 1367-1375, 2004.

SILVA, S. A.; LIMA, J. S. S. Multivariate Analysis and Geostatistics of the Fertility of a Humic Rhodic Hapludox under Coffee Cultivation. Revista Brasileira de Ciência do Solo, v. 36, n. 2, p. 467- 474, 2012.

SILVA, S. A.; LIMA, J. S. S.; ALVES, A. I. Estudo espacial do rendimento de grãos e porcentagem de casca de duas variedades de Coffea arabica L. visando a produção de café de qualidade. Bioscience Journal, v. 26, n. 4, p. 558-565, 2010.

TESIC, D. et al. Environmental effects on cv Cabernet Sauvignon grown in Hawke's Bay, New Zealand 1 - Phenology and characterization of viticultural environments. Australian Journal of Grape and Wine Research, v. 8, n. 1, p. 15-26. 2001.

VAN LEEUWEN, C. et al. Influence of climate, soil and cultivar on terroir. American Journal of Enology and Viticulture, v. 55, n. 3, p. 207-217, 2004.

VAZQUEZ, E. S.; SEGADE, S. R.; FERNANDEZ, I. O. Effect of the winemaking technique on phenolic composition and chromatic characteristics in young red wines. European Food Research and Technology, v. 231, n. 5, p. 789-802, 2010.

ZOU, J. F. et al. Elemental Patterns of Wine, Grape, and Vineyard Soil from Chinese Wine-Producing Regions and Their Association. American Journal of Enology and Viticulture, v. 63, n.1, p. 1-10, 2012. 